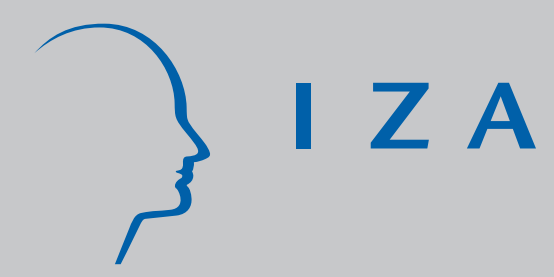

IZA DP No. 199

Rational Migration Policy Should Tolerate NonZero Illegal Migration Flows: Lessons from Modelling the Market for Illegal Migration

Horst Entorf

September 2000 


\title{
Rational Migration Policy Should Tolerate Non-Zero Illegal Migration Flows: Lessons from Modelling the Market for Illegal Migration
}

\author{
Horst Entorf \\ University of Wuerzburg, ZEW, Mannheim and IZA, Bonn \\ Discussion Paper No. 199 \\ September 2000 \\ IZA \\ P.O. Box 7240 \\ D-53072 Bonn \\ Germany \\ Tel.: +49-228-3894-0 \\ Fax: +49-228-3894-210 \\ Email: iza@iza.org
}

This Discussion Paper is issued within the framework of IZA's research area Mobility and Flexibility of Labor Markets. Any opinions expressed here are those of the author(s) and not those of the institute. Research disseminated by IZA may include views on policy, but the institute itself takes no institutional policy positions.

The Institute for the Study of Labor (IZA) in Bonn is a local and virtual international research center and a place of communication between science, politics and business. IZA is an independent, nonprofit limited liability company (Gesellschaft mit beschränkter Haftung) supported by the Deutsche Post AG. The center is associated with the University of Bonn and offers a stimulating research environment through its research networks, research support, and visitors and doctoral programs. IZA engages in (i) original and internationally competitive research in all fields of labor economics, (ii) development of policy concepts, and (iii) dissemination of research results and concepts to the interested public. The current research program deals with (1) mobility and flexibility of labor markets, (2) internationalization of labor markets and European integration, (3) the welfare state and labor markets, (4) labor markets in transition, (5) the future of work, (6) project evaluation and (7) general labor economics.

IZA Discussion Papers often represent preliminary work and are circulated to encourage discussion. Citation of such a paper should account for its provisional character. 
IZA Discussion Paper No. 199

September 2000

\section{ABSTRACT \\ Rational Migration Policy Should Tolerate Non-Zero Illegal Migration Flows: Lessons from Modelling the Market for Illegal Migration}

The debate on the immigration policies in OECD countries has turned its attention towards illegal migrants. Given that migration flows are determined by immigration laws, the probability of potential detection, penalties for unauthorised migrants and their employers, and on income differences between sending and receiving countries, this paper presents a new approach to the problem of illegal migration, grounded on the economic theory of illegal behaviour. The framework considers the interaction of potential migrants, citizens, employers, and the government. After introducing the supply function of illegal migration and its determinants, the trade-off between social costs and benefits of preventing and combating illegal migration is demonstrated. This trade-off results in an optimal level of migration larger than zero. A complete "market model" of illegal migration is offered by presentation of a demand curve of illegal migration, based on the tolerance of the society towards clandestine foreigners. Equilibrium forces predict a non-zero level of illegal migration. The rule of law of our legal systems, according to which any illegal activity has to be reduced to zero, bears the danger of producing inefficient disequilibria. A reasonable policy of wanted and unwanted migration should address the question of how to allocate scarce resources. Ignoring social optima and equilibrium forces means to abandon public resources that could be used for other public assignments, such as schooling, or foreign aid, for instance, i.e., measures that could strike the problem of illegal migration at its root.

Keywords: Illegal migration, rational behaviour, migration policy, social costs and benefits

JEL Classification: F22, D61

Horst Entorf

University of Wuerzburg

Department of Economics

Sanderring 2

D-97070 Wuerzburg

Germany

Tel.: +49-931312935

Fax: +49-931888 7097

Email: horst.entorf@mail.uni-wuerzburg.de 


\section{Introduction}

Illegal immigration has become a topic of common public concern. Estimating the clandestine migration flows is a delicate task, and estimates often may be just "guessestimates". At any rate, figures are quite high and rising. Some OECD countries publish figures for unauthorised immigrants (see Tapinos, 2000). They are estimated at between 4 and 5 million in the United States, and about 300,000 in Greece and Italy. In 1989-90, by the time of the fall of the iron curtain, in Germany the number of illegal alien workers quickly climbed to 500,000 or 1 million, or more (Martin and Teitelbaum, 1997). Thus, not surprisingly, the debate on the immigration policies in OECD countries has turned its attention towards illegal migrants, as can be seen from several recent publications, in particular by OECD consultants (Bratsberg, 1995, Yoshida, 1996, Djajic,1997, Borowski and Yanay, 1997, Jahn and Straubhaar, 1998, Martin, 1998, Robin and Barros, 1999, OECD, 1999, Garson 2000, and Tapinos, 2000).

Bad political, social and economic situations in the home country force people to leave their home country. Differences in job quality and pay belong to the primary reasons people are migrating. The destination and the number of illegal migrants are determined by immigration laws, the probability of potential detection, penalties for foreigners working without due authorisation, sanctions for employers of illegal foreign labour, and by the current economic and general economic situation of the receiving country.

The trade-off between potential utility improvements due to illegal actions on the one hand, and a potential worsening of the situation due to sanctions on the other hand, is well documented in the more general theory of illegal behaviour. ${ }^{1}$ This article tries to find out whether this theory could shed new light on the debate about illegal migration. The framework builds on the assumption that (illegal) migrants respond to (economic) incentives. The public's decision variables that might change the costs and benefits from illegal migration are expenditures on, for instance, border

\footnotetext{
${ }^{1}$ The most influential article is Becker's (1968) "Crime and Punishment: An Economic Approach". The use of the term "crime" might be considered provocative in some applications of his theory. Becker (1968, p. 170) himself emphazises that he uses the word "crime" to minimize terminological innovations. His analysis was intended to cover all violations of law, including violations like whitecollar crimes and traffic.
} 
enforcement, internal controls, and the form and severity of sanctions, including sanctions on employers of illegal migrants. In this paper, the relationship between public measures undertaken to prevent and combat illegal migration, and the number of illegal migrants will be introduced as "supply of illegal migration".

However, it is only the evolution of a complete "market model" that offers a comprehensive framework for studying the problem. The missing demand link is based on the degree of the society's tolerance to illegal migrants. The attitude of citizens, voters and policy-makers towards illegal migrants depends on the prevailing number of (illegal) migrants in the society, particularly in the presence of high unemployment rates. Political pressure and xenophobic interests might lead politicians to fight illegal immigration, such that measures of curbing illegal migration are tightened up. The "demand" for illegal migration would fall.

It might strike sociologists, political scientists, lawyers, public management specialists, and other disciplines who study the problem of illegal migration, as rather strange to apply the idea of economic market forces to illegal migration. However, a quick look at university courses on migration, for instance, reveals that among the most prominent course topics, we find "push/pull" factors " of sending and receiving areas (in the sense of "classical" migration theory, "push" factors represent the impact of origin characteristics upon migration, while the "pull" factors demonstrate the influence of destination characteristics). ${ }^{2}$ Thus, researchers are quite aware of the problem of interacting forces that determine the (equilibrium) level of actual migration, though attempts to relate the illegal migration problem to economic demand and supply functions are rare. ${ }^{3}$

Demand and supply of illegal migration state an equilibrium at non-zero migration flows (see Section 4). Also, the minimisation of social costs from illegal migration predicts optimal migration to be a positive number (see Section 3). Put equivalently, although more strangely, the economic approach comes down to the question "How many illegal migrants should be permitted and how many illegal migrants should

\footnotetext{
${ }^{2}$ Examples for the analysis of push/pull factors in scientific articles are Clark, Knapp, and White (1996), Zimmermann (1996), and O'Connel (1997).

${ }^{3}$ Jahn and Straubhaar (1998) provide an exception by pointing at the "microeconomics of the market for illegal immigrants", and by surveying research results from the viewpoint of supply and demand of illegal foreign workers.
} 
pass the border and work illegally?" This consequence of the economic approach to illegal migration might be difficult to accept, in particular in the face of existing judicial systems, according to which any illegal activity should be banned. However, the optimal policy of wanted and unwanted migration is a question of the optimal allocation of resources. It has to be decided whether scarce public resources should be spend for fighting illegal migration, or whether it might be preferable to use these resources otherwise.

This paper is organised as follows. Section 2 describes the current economic situation of illegal migrants, their decision process, and the ensuing supply of illegal migration. Section 3 presents the rational behaviour of the society that is interested in minimising social costs from illegal migration. In Section 4 , the demand side is added to the market model by relating migration flows to the tolerance level of citizens (and their political representatives) towards illegal migration. Section 5 concludes.

\section{Individual rationality, the trade-off between risk and opportunity, and the supply of illegal migration}

\section{Incentives to migrate, and to employ undocumented migrants: High (illegal) income opportunities}

„In a world of winners and losers, the losers do not simply disappear, they seek somewhere else to go", says Stalker, in a recent ILO publication (Stalker, 2000). The expected net utility from leaving one country and entering an other country depends on the economic conditions in the sending and receiving countries. Differences in job quality and pay belong to the primary reasons people are migrating. Incentives of illegal labour supply on the one hand, and of illegal labour demand in the receiving country on the other hand, can be seen by looking at labour costs: In 1995, hourly labour costs in manufacturing stood at US\$ 0.25 in India and China, US\$ 0.46 in Thailand, US\$ 0.60 in Russia, US\$ 1.70 in Hungary, and US\$2.09 in Poland, against US\$13.77 in the United Kingdom, US\$16.03 in Canada, US\$17.20 in the United States, US\$19.34 in France, US\$23.66 in Japan, and US\$ 31.88 in 
Germany (Stalker, 2000). Expectations based on these figures makes potential future risks and dangers less daunting.

Inspecting average wages in industrialised countries might be misleading, because not all occupations are open to immigrants. Nevertheless, there are strong incentives to hire foreign workers, both authorised and unauthorised. Garson (2000), based on a study of six OECD countries - France, Greece, Italy, Portugal, Spain, and the United States -, has identified certain core sectors in which foreign labour is employed: agriculture, building and civil engineering, small-scale industry, tourism, hotels and catering, and services to households and to businesses, including computer services. Among the first and foremost reasons to hire immigrant labour, Garson (2000) points out the greater flexibility to production work, for example when performing arduous and intensive seasonal farming activities, and the constant endeavour to minimise costs, especially in Europe and the United States. Here, many employers misuse the precarious situation and low bargaining power of undocumented workers who are desperate for work. Tapinos (2000) points out that the "welfare magnet" of illegal migration therefore is much stronger for the employer than for the worker.

Illegal migrants are increasingly present in service jobs now shunned by nationals, particularly sanitation and cleaning. The growth of the service sector, in particular of services to businesses, such as equipment maintenance and servicing, caretaking, catering, and retail trading has been favourable to unauthorised workers. The growth in outsourcing and subcontracting are further recent trends that lead to higher demand for illegal migrants to minimise costs. The urgent need of the European countries for computer experts and hospital services provide strong incentives to hire unauthorised foreigners. Garson (2000) reports that in countries like France and Italy, undocumented skilled foreigners find work in science and language teaching, as well in hospital services, though usually at much lower pay than for national personnel. Most important is the relative wage gap between countries. According to Stalker (2000), Indonesia, for instance, exports unskilled labour to the Middle East, Malaysia, and Singapore, and imports skilled workers, mostly from India and the Philippines. 
Achievements in social security of industrialised countries are further determinants of migration flows. For instance, Siklos and Marr (1998) have explored the relationship between province of residence and the use of unemployment insurance (UI) among immigrants who landed in Canada during the period 1981-88. Their main conclusion is that more generous $\mathrm{UI}$ benefits and poorer economic conditions than the national average have a positive impact on the fraction of immigrants who receive UI.

As a more general and overall result, Karras and Chiswick (1999) find that long-run trends of migration are determined by the degree and speed of per capita income convergence between the sending and receiving countries, while year-to-year changes in net migration flows are dominated by cyclical economic conditions. Results of this kind are confirmed by Stalker (2000), who points at differences in living standards in terms of GDP per capita between, for instance, the United States and Mexico (6:1), and Germany and Poland (11:1). Information about the economic situation in neighbouring countries is well known to potential emigrants, and migrants are sensitive to changes of the economic situation. Stalker (2000) refers to a US study by the Public Policy Institute of California, which has found that when California's economy boomed in the mid to the late 1980s, the state experienced rapid job growth and illegal immigration peaked. On the other hand, when California suffered from a severe recession in the early 1990s, undocumented immigration fell.

\section{Disincentives to move: Risks of being detected and sanctioned, costs of migration}

The high number of illegal migrants has also led to the emergence of a lucrative illegal income opportunity of some different kind, i.e., of activities within the "trafficking industry". According to Stalker (2000), 15-30\% of undocumented immigrants were thought to have used the services of traffickers. "Smuggling someone by car across an European border or by boat from Maroccco to Spain might be worth US\$500, but a sophisticated travel package for an undocumented migrant from China to the United States can cost up to US\$30,000" (Walker 2000). From the viewpoint of potential illegal migrants, these sums are costs that diminish the net benefit from leaving the home country. The same holds for the possibility to 
enter by using forged documents. Bangkok seems to be a major market for forged Korean and Japanese passports - worth about US\$2,000 apiece (Stalker, 2000).

Other disincentives to move come from social and political pressures in host countries. There is evidence of growing resistance to new arrivals. Borowski and Yanay (1997), for instance, report about recent initiatives to reduce the number of illegal migrants coming to Israel from many countries outside the Middle East region. Based on a questionnaire sent out to OECD member countries, a report prepared by the OECD secretariat, analysing measures undertaken to prevent and combat illegal employment of foreigners, says that "most Member countries have decided to step up enforcement against illegal employment of foreigners, and to bring in penalties for traffickers and middlemen" (Robin and Barros, 1999, § 58). The strongest opponents of further immigration are former migrants, as can be seen from the US, a country built by immigrants. Most US polls (The Economist, 2000) show that around twothirds of the population would like to reduce further immigration. Seen from the viewpoint of those (legal) migrants who arrived during recent immigration waves, resistance is understandable. They are most vulnerable to the effect of illegal immigration on wages, and they may be crowded out of legal work at given wages, particularly when unemployment is high.

A lower degree of tolerance towards illegal migration negatively affects the expected net gain from moving. Because in the unlucky case of detection higher sanctions would imply higher potential utility losses, these have to be subtracted from potential income opportunities and wealth gains. The expected loss depends on the probability of detection, and on the penalty itself. Both are likely to be increased, for instance, in reaction to xenophobic movements, in proximity of elections, and in the presence of high unemployment. As indicated by the OECD report on the prevention and fight against illegal employment of foreigners (Robin and Barros, 1999), potential sanctions are quite high and stiffening, but the probability of detection still seems to be rather low.

As regards sanctions, policies to curb illegal migration usually include expulsion measures applicable to foreigners who breach immigration rules because they lack authorisation to reside or work in the country. In case of illegal employment, further sanctions are designated, including imprisonment or fines. In France, for instance, 
working foreigners without residence permits face criminal sanctions up to one year in prison and fines up to FF 25,000 (i.e. Euro 3811). In the UK, imprisonment for up to six month is possible, and in Germany, a foreigner without a permit is liable to an administrative fine up to DM 10,000 (Euro 5113) (Source: Robin and Barros, 1999).

It is questionable whether such sanctions are effective measures to deter the majority of illegal migrants, who do not have much they could lose. In fact, most of the OECD countries consider the employer to be the leading party in illegal employment. The following examples, taken from Robin and Barros (1999), may give an impression of potential sanctions for those employers who take advantage of the insecure situation of foreign workers. In the Netherlands, sentencing guidelines according to the Employment of Foreigners Act recommend a fine of f. 2,000 (Euro 908) per illegal worker, in the case of first offence. For subsequent offences, the judge is recommended to order a months's imprisonment and closure of the firm. Since 1994, employers are also liable to criminal sanctions under the Penal Code for employing illegal migrants. The penalties here are imprisonment for up to a year and a fine of up to f. 100,000 (Euro 45,378). In Spain, firms employing foreigners without permits face administrative fines of between Ptas 500,000 (Euro 3,005) and 15,000,000 (Euro 90,152) for each illegal worker. In France, any person who hires someone without due authorisation to work faces a penalty of up to three year's imprisonment and/or a fine of FF 30,000 (Euro 4,573), for each illegal worker. In Germany, employer first face a regulatory fine of up to DM 500,000 (Euro 255,646). Employment of foreigners without work permit may also give rise to criminal sanctions, when more than 5 foreign workers are involved, or when foreigners are employed for a period of 30 days or more, or when the offence is deliberate and repeated. Then employers face a fine or imprisonment of up to a year.

Moreover, as discussed in the debate over Proposition 187 in California, deterrence could also be based on punishing illegal migrants by barring illegal alien children from public schools (see Martin, 1998, for a discussion of this point). Furthermore, instrumenting the means of the severity of punishment also includes fines for the trafficker who helps migrants entering the desired country.

Despite high sanctions, illegal migration has remained a major problem of public concern. Evidently, the probability of detection is quite low, such that expected gains 
from entering and working illegally remain high compared to expected risks and costs. Not surprisingly, the OECD report hints at this weak point, when it summarises the attempts of the OECD member states to curb illegal employment: "Preventive measures are relatively modest, set against the range of penalties in most countries' legislation. They are largely confined to information drives, aimed particularly at employers, to border controls and to financial incentives to employ documented workers" (Robin and Barros, 1999).

Also falling transportation and communication costs ease migration, making it much less a permanent move. Stalker (2000) provides data according to which air transport costs per mile by 1990 had dropped to $20 \%$ of their 1930 level. Moreover, between 1930 and 1996, the cost of a three-minute telephone conservation between London and New Yew fell from US\$ 300 to US\$1.

\section{Formalising ideas: The rational choice of illegal migration, and the supply of illegal migration}

The description of the economic circumstances of illegal migration focuses on three basic elements: a) the income differential between the receiving and the sending countries, b) the severity of sanctions, and c) the probability of being detected. This situation fits the point of departure of the more general theory of illegal behaviour, in which the considered income differential would be the difference between low legal income opportunities in the home country, and high and risky illegal income opportunities in the host county. Theories on illegal behaviour based on the assumption of rational choice were already proposed by Bentham (1788, 1843), whose main ideas were vitalised and modernised in the seminal article by the later Nobel price winner Gary S. Becker (1968). Using this approach, illegal immigrants are treated like anyone else, who behaves as rational utility maximiser, and who responds to economic incentives.

As the total outcome of illegal migration is uncertain, people act as if they were maximising expected utility, and also that utility is a positive function of income. The potential illegal migrant's expected utility $E[U]$ from entering illegally is

$$
E[U]=p U(Y-f)+(1-p) U(Y),
$$


where $U($.$) is the individual's (von Neumann-Morgenstern) utility function. p$ is the probability of being detected and punished. It depends on the size of the personnel involved in external border controls, police and immigration services for internal employment checks, international cooperation etc. The severity of the punishment $f$ deters potential attempts to enter the country. As has been seen above, "punishment" of illegal migrants could have several meanings. It could mean fines, imprisonment, but also "removal" with the risk of returning to the bad previous situation, and with the consequence that all investments that have been spent in order to get into the country were lost. For most illegal migrants, this probably is the worst case. Fines and punishments are expressed in monetary equivalents to keep ideas clear.

$Y$ is the potential monetary income (or monetary equivalent) from illegal migration. Hence, $p U(Y-f)$ presents the expected (dis-)utility from migration in the (unlucky) case of being detected and punished. It could remain positive if potential illegal income opportunities are high. $(1-p)$ is the probability of escaping detection, and $(1-p) U(Y)$ is the expected utility from a successful illegal migration.

It is important to note that $Y$ varies with changing sanctions for the employers. Frequent authorisation checks, for instance, makes hiring illegal workers a risky business, and increasing sanctions for employers reduce the incentive to employ foreigners without work permit (given that the probability of detection is noticeable). As a consequence, the demand for illegal labour would decrease at given wages, or, if illegal labour supply is rigid, "profitable" wages of illegal workers would drop, such that potential income opportunities from illegal migration are falling. Moreover, other measures like increasing minimum wages have an effect on $\mathrm{Y}$. Higher minimum wages increase the attraction to employers of hiring illegal immigrants, such that the higher demand for illegal labour leads to higher expected illegal income opportunities.

As can be seen easily, increasing $p, f$ or both of them reduces the expected payoff $E[U]$. In that case in which utility coincides with income ( $U$ is an identity, i.e., in the case of risk neutrality), the result boils down to

$$
E[U]=Y-p f .
$$


Whether individual migration takes place or not, depends on the value of the expected utility from illegal migration, and the utility of staying (and working) in the source country which is known by experience. If the difference between the two values is larger than zero, the decision is in favour of migrating. The higher the income difference $d$ between receiving and sending countries is, and the smaller $p$ and $f$ are, the higher is the number of illegal migrants. Thus, at the aggregate level, we can write the supply of illegal migration $M$ in general functional form as

$$
M=M(d, p, f, u),
$$

where $u$ is a portmanteau variable that represents remaining influences, which are not considered here. In terms of first derivatives, expect effects are $\frac{\partial M}{\partial d}>0, \frac{\partial M}{\partial p}<0, \quad$ and $\frac{\partial M}{\partial f}<0$.

\section{Social Rationality: Minimising social costs from illegal migration}

Borders without control, and free illegal work of foreigners would cause social costs that are not feasible for receiving societies, at least in the short-run ${ }^{4}$ (due to expenses for social assistance, crowding out of nationals, credibility of judicial systems, growing xenophobic interests and social unrest, etc.). Thus, policy-makers take measures to prevent and combat illegal migration, and to curb employment of foreigners in irregular situations. As can be seen from the OECD report (Robin and Barros, 1999), measures focus on increasing the probability of detection, $p$, and on the severity of sanctions, $f$.

The economic problem arises because increasing $p$ and $f$ may have the wanted effect of reduced immigration, but the success comes with additional costs. Preventing any migration crime would be impossible because of the unacceptable costs of total control. Thus, the social optimum is somewhere between zero migration and laissez-faire. Put equivalently, although more strangely, the economic

\footnotetext{
${ }^{4}$ In the long-run, a different view has to be taken. The unbalanced pension systems of industrialised countries, for instance, are in urgent need of young (but legal) workers. Without immigrants, rich host countries tend to get old.
} 
approach comes down to the question "How many illegal migrants should be permitted and how many illegal migrants should pass the border and work illegally?" For many politicians who are used to think as lawyers, the consequence of optimal non-zero flows of illegal migration is not easy to accept, since for them any illegal activity should be banned. However, the optimal policy of wanted and unwanted migration is a question of the optimal allocation of resources. It has to be decided whether scarce public resources should be spend for fighting illegal migration, or whether it might be preferable to use these resources otherwise. For instance, from a long-run perspective, a reasonable alternative could be to improve schooling in the sending countries.

To analyse the trade-off between costs of curbing illegal migration and social costs of illegal migration in more detail, we can borrow from Becker's (1968) basic theory of illegal behaviour. Policy instruments have to be chosen such that social costs from illegal migration will be minimised. Policy-makers' instruments consist of varying the probability of detection, $p$, and the form and size of sanctions, $f$. Social costs consist of two main components, "direct social costs", $D$, and "indirect social costs", $C$ :

$$
L=D(p, f)+C(M) .
$$

First, indirect social costs, $C$, consist of the deficient amount of welfare contributions: Employers and illegal migrants negotiate their work contract without giving the legal part of the population its piece of the cake. The effect is particularly strong if local unskilled workers will be substituted by illegal migrants. Financial contributions to the social security system would diminish, and public infrastructure would degrade, if the share of illegal workers increases. A further cost component is related to crime. Illegal migrants are mainly young and male. The cohort of young males is the most active one of all population groups, and "active" means being "active" concerning both, legal and illegal activities. Hence, as is well known from crime statistics, the cohort of young males has the highest crime rates, no matter which nationality they have, such that higher costs of crime would emerge in the 
presence of (mainly young and male) immigration. ${ }^{5} C$ is a function of the number of illegal migrants, $M$, which itself depends on the probability of detection, $d$, and on sanctions, $f$. $C$ may be thus called indirect social costs.

Direct costs, $C$, depend on the parameters of deterrence, $p$ and $f$, in a more direct way. Direct costs are caused by costs of border control, employer control, information drives, apprehension, police, administrative personnel, imprisonment, custody, removal flights etc. Both components, $D$ and $C$, are affected by $p, f$ in opposite ways:

$$
\begin{gathered}
D \underset{(+)}{\Leftarrow} p, f \\
C \underset{(+)}{\Leftarrow} M \underset{(-)}{\Leftarrow} p, f
\end{gathered}
$$

Whereas a higher level of deterrence increases direct costs, it will lower indirect cost via deterring potential migrants, and employers of illegal migrants. Assuming usual neoclassical functional forms for the cost functions $C$ and $D$ (both first and second derivatives positive), optimal levels of deterrence exist (see Becker, 1968, for the original model of this kind). The optimum then can be interpreted in the usual way: Extending $p$ and $f$ increases the marginal costs of deterrence and decreases the marginal revenue from avoiding illegal migration. The optimum will be reached when the costs of marginally increasing control etc. will become higher than the additional revenue from stopping another migrant. Following these arguments, it becomes clear that extending (costly) deterrence does not make sense beyond the optimal levels of border control, internal control, control of employment, severity of sanctions etc. Any attempt to further reduce illegal immigration towards zero would imply renouncement of public resources.

\footnotetext{
${ }^{5}$ Entorf and Spengler (2000) analyse factors of crime in Germany. It turns out that (after controlling for several other socio-economic determinants of crime) larger cohorts of young men and, in particular, larger groups of young unemployed are associated with higher crime rates. Moreover, foreigners in Germany seem to commit crimes mainly for economic reasons. For crimes against the person, there is no significant indication that the behaviour of Non-Germans in Germany is different from that of Germans in Germany. It goes without saying that all reasoning about crime and illegal migrants mentioned here is based on correlation, not on causation. True reasons of higher crime rates are different from simply being an undocumented foreigner. Potential social costs from illegal migration, however, would be incomplete without considering this cost component.
} 
On the one hand, the optimum primarily depends on how elastically illegal migration $M$ reacts to changes of deterrence, given by changes of $p$ and $f$, and to the costs of stricter enforcement on the other hand. There are, however, more exogenous instruments left for immigration policy. They shift curves of marginal revenues and marginal costs, so that the optimal degree of deterrence and the corresponding number of illegal migrants change. For instance, lowering the tax burden for employers or lowering minimum wages would flatten the indirect cost curve $C$, because there would be lower incentives to substitute unskilled workers by illegal immigrants. As a result, the degree of optimal deterrence and corresponding (optimal) social costs might decrease. ${ }^{6}$

\section{Tolerance of illegal migration, and the market equilibrium of illegal migration}

The traditional theory of illegal behaviour (Becker, 1968, Ehrlich, 1973) explains how the level of illegal activities emerges through the interplay of public policy (degree of deterrence) and illegal migration decisions. This approach neglects the interplay with other citizens (voters) of the society. Their attitude towards illegal migrants depends on the prevailing level of illegal migration in the society, particularly in the presence of high unemployment rates. A high influx of (illegal) immigrants diminishes the degree of tolerance towards illegal migration. Political pressure and xenophobic interests lead politicians to fight illegal immigration, such that measures of deterrence are tightened up. This makes illegal migration less attractive, because the "price" migrants have to pay for illegal migration goes up, and the expected payoff from illegal migration is reduced. The "demand" for illegal migration would fall.

Ehrlich (1996) has applied similar arguments to incorporate the demand side in the general theory of crime: Demand for illegal activity is determined by the tolerance of crime in the society. In the context of illegal migration, the complete market model is depicted in Figure 1. $q$ is the number of illegal migrants per citizen. The supply of

\footnotetext{
${ }^{6}$ From a general equilibrium point of view, the lower costs from illegal immigration might be offset by lower legal tax incomes from the lower wages of legal workers. Thus, among other things, the net value depends on the tax elasticity of legal incomes.
} 
illegal migrants per citizen depends on the expected profit per illegal migrant migration, $\pi$. It is a function of the expected sanction, $p f$, the expected pay for illegal work in the receiving country, the (possibly zero) pay in the host country, and travel costs (incl. costs of preparation, information, paying of traffickers etc.) (see Section 2). When expected returns from illegal migration increase, the number of illegal migrants will increase, as is shown in the supply curve ss of Figure 1.

Figure 1: The market for illegal migration

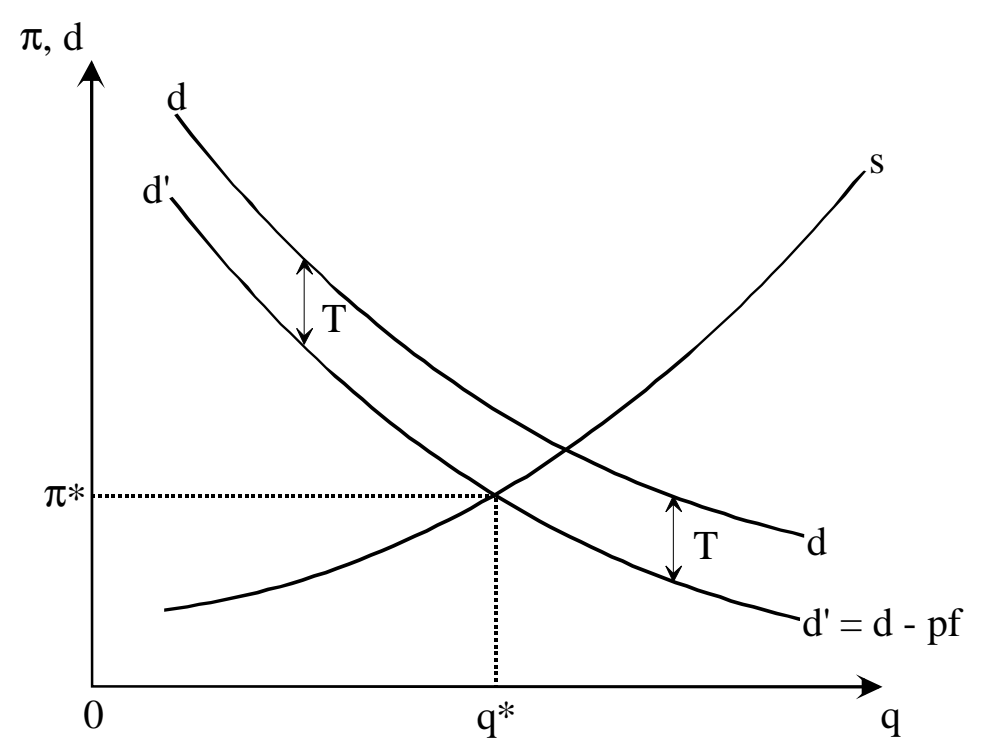

The degree of a society's tolerance towards migration determines the expected utility from entering the host country, and from hiring undocumented foreigners. By analogy to the supply of illegal migration, and to complete the market for illegal migration, it may be called the demand curve of illegal migration. The functional form of the curve is determined by the degree of resistance against illegal migration. The private demand is depicted by the curve $d d$. Increasing illegal migration results in higher resistance of citizens (so that the curve might also be called the "intolerance curve" of private citizens). ${ }^{7}$ Moreover, a higher number of migrants per citizen leads to increasing competition among illegal migrants, which forces them to accept lower wages and more risky jobs, so that the expected wage income decreases. Thus, an

\footnotetext{
${ }^{7}$ This includes growing resistance of legal immigrants. They took a harder way to get into the receiving country whereas those coming illegally "... sneaked in from the side without lining up properly" (Jahn and Straubhaar, 1998, p. 9).
} 
increasing number of illegal migrants per citizen $q$ reduces the potential payoff per migrant, and it increases the cost of migration. Hence, $q$ is negatively associated with the demand for migration.

However, the intercept of $d d$ and ss does not suffice to describe the market equilibrium, because private citizens do not care about public welfare. Social costs have to be minimised according to the rules and goals presented in Section 3. Here, optimised public expenditures on law enforcement, the optimal choice of $p$ and $f$, and the resulting expected sanction $p f$ come into play. In a market model, $T=p f$ can be treated as a "tax" on illegal migration. Thus, public enforcement implies that private demand will be reduced by $p f$ in order to get total demand.

The market is in equilibrium when the number of migrants per citizen is such that neither (potential) illegal migrants, private citizens nor government find it necessary to adjust their behaviour. The model implies that illegal migration is a "normal" social fact. Illegal migration persists because the interplay between supply and demand forces imply that some level of illegal migration will remain socially optimal.

Attempts to reduce illegal migration below its equilibrium level, or tolerating more than the equilibrium number of illegal migrants, means maintaining a permanent market disequilibrium. For instance, extending control beyond the equilibrium level causes excess demand for illegal migration. Irregular employers "demand" more illegal migrants than they receive from sending countries. There would be strong incentives to fill this excess demand. Thus, preventing equilibrium forces implies the acceptance of permanent adjustment dynamics, and of excess enforcement costs. It implies wasting public resources. Saved resources could be used to improve the social and economic situation in the source country of illegal migrants.

\section{Conclusions}

The debate on the immigration policies in OECD countries has turned its attention towards illegal migrants. One of the main conclusions is that neither a regime of regular migration such as that in North America nor one of closed borders such as that prevailing in Europe guarantees the containment of clandestine entries and residence of foreigners in an irregular situation (see OECD, 1999, p. 246 for this 
conclusion). This paper sheds some light on the reasons and the consequences of this result.

Differences in wages and living standards belong to the primary reasons people are migrating. Moreover, immigration flows are determined by immigration laws, the probability of potential detection, and penalties for unauthorised migrants and their employers in the receiving country. Based on the assumption that illegal migrants, citizens and policy-makers respond to economic incentives, this paper presents recent trends in curbing illegal migration, and proposes to approach the problem of illegal migration by using insights known from the economic theory of illegal behaviour. The presented framework allows for a simultaneous consideration of the interplay of migrants, citizens, employers, and the government. It is used to derive the supply function of illegal migration, and to illustrate the trade-off between costs and benefits of preventing and combating illegal migration. This trade-off results in an optimal level of non-zero migration. Beyond a certain level of control the costs to avoid illegal migration are higher than the social costs caused by illegal migration.

A complete "market model" of illegal migration is offered by adding a demand for illegal migration that is based on the tolerance of the society towards clandestine foreigners. As already predicted by minimising social costs of illegal migration, demand and supply of illegal migration result in an equilibrium of positive migration flows. This result might be quite difficult to accept for policy-makers, who are used to the principle that any illegal activity has to be reduced to zero. However, the optimal policy of wanted and unwanted migration is a question of the optimal allocation of resources. It has to be decided whether scarce public resources should be spend for fighting illegal migration, or whether it might be preferable to use these resources for other urgent needs of public health care, or schooling, for instance. In particular, ignoring social optima and equilibrium forces means abandoning resources for foreign aid that could strike the problem of illegal migration at its root. 


\section{References}

Becker, G.S. (1968), Crime and punishment: An economic approach, Journal of Political Economy, 76, 169-217.

Bentham, J. (1843), Principles of Penal Law, in Works 1, 399.

Borowski, A., and U. Yanay (1997), Temporary and illegal labour migration: The Israeli Experience, International Migration, 35(4), 495-511

Bratsberg, B. (1995), Legal vs. Illegal US immigration and source country characteristics, Journal of International Economics, 715-726.

Clark, D. E., Knapp, T.A. and White, N.E. (1996), Personal and location-specific characteristics and elderly interstate migration, Growth and Change, Summer 1996, 27(3).

Djajic, S. (1997), Illegal immigration and resource allocation, International Economic Review, 38, 97-117.

Ehrlich, I. (1973), Participation in illegitimate activities: A theoretical and empirical investigation, Journal of Political Economy, 81(3), 521-565.

Ehrlich, I. (1996), Crime, punishment, and the market for offenses, Journal of Economic Perspectives, 10, 43-67.

Entorf, H. and H. Spengler (2000), Socio-economic factors of crime in Germany: Evidence from panel data of the German states, International Review of Law and Economics 20, 75-106

Garson, J.-P. (2000), Where do illegal migrants work?, OECD Observer, March 8, 2000, http://www.oecdobserver.org.

Jahn, A. and T. Straubhaar (1998), A survey on the economics of illegal migration, South European Society \& Politics, 3(2), a preliminary version is available at http://migration.ucdavis.edu/mm21/SanDiego2-11/Straubhaarlllegallmmig.html.

Karras, G., and C.U. Chiswick (1999), Macroeconomic determinants of immigration: The case of Germany, 1964-1988, International Migration, 37(4), 657-677

Martin, P., and M. Teitelbaum (1997), Report of the seminar on Immigration, Integration, and Enforcement, Focus on Berlin and Poland, April 24-26, 1997 in Berlin, Germany, available at http://migration.ucdavis.edu/mda/ber.html.

Martin, S. (1998), Politics and policy resonses to illegal migration in the U.S., Paper presented to the Conference on Managing Migration in the 21st Century, June 2123, 1998, Hamburg, http://migration.ucdavis.edu/mm21/Susan.html.

O' Connell, P.G.J. (1997), Migration under Uncertainty: "Try Your Luck" or "Wait and See", Journal of Regional Science, 37(2).

OECD (1999), Trends in International Migration, Part III: "Clandestine Immigration: Economic and Political Issues" (special chapter written by G. Tapinos), OECD Continuous Reporting System on Migration (SOPEMI), Annual Report, Paris: OECD 
Robin, S., and L. Barros (1999), Measures undertaken to prevent and combat the employment of foreigners in an irregular situation in certain OECD member countries, OECD document DEELSA/ELSA/MI(99)4, 20-April-1999.

Siklos, P.L. (1998), The unemployment insurance compensation usage of Canada's immigrants in selected provinces, 1981-1988, International Migration, 36(3), 337356

Stalker, P. (2000), Workers Without Frontiers - The Impact of Globalization on International Migration, International Labour Organization (ILO), Geneva: Lynne Rienner Publishers, all quotes are taken from the ILO press release ILO/00/2.

Tapinos, G. (2000), Illegal immigrants and the labour market, OECD Observer, March 8, 2000, http://www.oecdobserver.org.

The Economist (2000), Oh, say, can you see? Immigration will reshape America more profoundly than trade or technology, Survey: The United States, http://www.economist.com/4j3zdT3l/editorial/freeforall/20000311/index survey.html.

Yoshida, C. (1996), The global welfare of illegal immigration, Indian Journal of Economics, 74, 538-550.

Zimmermann, Klaus F. (1996), European Migration: Push and Pull, International Regional Science Review, 19(1\&2). 


\section{IZA Discussion Papers}

\begin{tabular}{|c|c|c|c|c|}
\hline No. & Author(s) & Title & Area & Date \\
\hline 101 & $\begin{array}{l}\text { L. Husted } \\
\text { H. S. Nielsen } \\
\text { M. Rosholm } \\
\text { N. Smith }\end{array}$ & $\begin{array}{l}\text { Employment and Wage Assimilation of Male First } \\
\text { Generation Immigrants in Denmark }\end{array}$ & 3 & $1 / 00$ \\
\hline 102 & $\begin{array}{l}\text { B. van der Klaauw } \\
\text { J. C. van Ours }\end{array}$ & $\begin{array}{l}\text { Labor Supply and Matching Rates for Welfare } \\
\text { Recipients: An Analysis Using Neighborhood } \\
\text { Characteristics }\end{array}$ & $2 / 3$ & $1 / 00$ \\
\hline 103 & K. Brännäs & $\begin{array}{l}\text { Estimation in a Duration Model for Evaluating } \\
\text { Educational Programs }\end{array}$ & 6 & $1 / 00$ \\
\hline 104 & S. Kohns & $\begin{array}{l}\text { Different Skill Levels and Firing Costs in a } \\
\text { Matching Model with Uncertainty - } \\
\text { An Extension of Mortensen and Pissarides (1994) }\end{array}$ & 1 & $1 / 00$ \\
\hline 105 & $\begin{array}{l}\text { G. Brunello } \\
\text { C. Graziano } \\
\text { B. Parigi }\end{array}$ & $\begin{array}{l}\text { Ownership or Performance: What Determines } \\
\text { Board of Directors' Turnover in Italy? }\end{array}$ & 1 & $1 / 00$ \\
\hline 106 & $\begin{array}{l}\text { L. Bellmann } \\
\text { S. Bender } \\
\text { U. Hornsteiner }\end{array}$ & $\begin{array}{l}\text { Job Tenure of Two Cohorts of Young German Men } \\
1979 \text { - 1990: An analysis of the (West-)German } \\
\text { Employment Statistic Register Sample concerning } \\
\text { multivariate failure times and unobserved } \\
\text { heterogeneity }\end{array}$ & 1 & $1 / 00$ \\
\hline 107 & $\begin{array}{l}\text { J. C. van Ours } \\
\text { G. Ridder }\end{array}$ & $\begin{array}{l}\text { Fast Track or Failure: A Study of the Completion } \\
\text { Rates of Graduate Students in Economics }\end{array}$ & 5 & $1 / 00$ \\
\hline 108 & $\begin{array}{l}\text { J. Boone } \\
\text { J. C. van Ours }\end{array}$ & $\begin{array}{l}\text { Modeling Financial Incentives to Get Unemployed } \\
\text { Back to Work }\end{array}$ & $3 / 6$ & $1 / 00$ \\
\hline 109 & $\begin{array}{l}\text { G. J. van den Berg } \\
\text { B. van der Klaauw }\end{array}$ & $\begin{array}{l}\text { Combining Micro and Macro Unemployment } \\
\text { Duration Data }\end{array}$ & 3 & $1 / 00$ \\
\hline 110 & $\begin{array}{l}\text { D. DeVoretz } \\
\text { C. Werner }\end{array}$ & $\begin{array}{l}\text { A Theory of Social Forces and Immigrant Second } \\
\text { Language Acquisition }\end{array}$ & 1 & $2 / 00$ \\
\hline 111 & $\begin{array}{l}\text { V. Sorm } \\
\text { K. Terrell }\end{array}$ & $\begin{array}{l}\text { Sectoral Restructuring and Labor Mobility: } \\
\text { A Comparative Look at the Czech Republic }\end{array}$ & $1 / 4$ & $2 / 00$ \\
\hline 112 & $\begin{array}{l}\text { L. Bellmann } \\
\text { T. Schank }\end{array}$ & $\begin{array}{l}\text { Innovations, Wages and Demand for } \\
\text { Heterogeneous Labour: New Evidence from a } \\
\text { Matched Employer-Employee Data-Set }\end{array}$ & 5 & $2 / 00$ \\
\hline 113 & R. Euwals & $\begin{array}{l}\text { Do Mandatory Pensions Decrease Household } \\
\text { Savings? Evidence for the Netherlands }\end{array}$ & 3 & $2 / 00$ \\
\hline 114 & $\begin{array}{l}\text { G. Brunello } \\
\text { A. Medio }\end{array}$ & $\begin{array}{l}\text { An Explanation of International Differences in } \\
\text { Education and Workplace Training }\end{array}$ & 2 & $2 / 00$ \\
\hline 115 & $\begin{array}{l}\text { A. Cigno } \\
\text { F. C. Rosati }\end{array}$ & $\begin{array}{l}\text { Why do Indian Children Work, and is it Bad for } \\
\text { Them? }\end{array}$ & 3 & $2 / 00$ \\
\hline
\end{tabular}


117 S. Bender

A. Haas

C. Klose

118 M. A. Shields M. E. Ward

119 A. Lindbeck

D. J. Snower

120 P. T. Pereira

P. S. Martins

121
J. C. van Ours

122

D. Munich

J. Svejnar

K. Terrell

123 J. Hunt

124 R. T. Riphahn

125 F. Büchel

J. R. Frick

126 J. Fersterer

R. Winter-Ebmer

127 M. Karanassou

D. J. Snower

128

O. Ashenfelter

D. Ashmore

O. Deschênes

129 B. R. Chiswick

M. E. Hurst

130
G. Brunello
S. Comi
C. Lucifora

131 B. R. Chiswick

R. A. Hart

133

IAB Employment Subsample 1975-1995.

Opportunities for Analysis Provided by the

Anonymised Subsample

Improving Nurse Retention in the British National

Health Service: The Impact of Job Satisfaction on

Intentions to Quit

The Division of Labor and the Market for

Organizations

Does Education Reduce Wage Inequality?

Quantile Regressions Evidence from Fifteen

European Countries

Do Active Labor Market Policies Help Unemployed 4/6 3/00

Workers to Find and Keep Regular Jobs?

Returns to Human Capital under the Communist

Wage Grid and During the Transition to a Market

5

$2 / 00$

Economy

Why Do People Still Live in East Germany?

Rational Poverty or Poor Rationality? The Take-up 3

The Income Portfolio of Immigrants in Germany -

Who Gains from Income Re-Distribution?

Smoking, Discount Rates, and Returns to

Education

Characteristics of Unemployment Dynamics: The

Chain Reaction Approach

Do Unemployment Insurance Recipients Actively

Seek Work? Evidence From Randomized Trials in

Four U.S. States

The Employment, Unemployment and

Unemployment Compensation Benefits of

Immigrants

The Returns to Education in Italy: A New Look at the Evidence

Are Immigrants Favorably Self-Selected? An

Economic Analysis

Hours and Wages in the Depression: British $7 \quad 3 / 00$ Engineering, 1926-1938

Paid and Unpaid Overtime Working in Germany and 1

R. A. Hart

O. Hübler the UK 
134 A. D. Kugler

G. Saint-Paul

135 A. Barrett

P. J. O'Connell

136 M. Bräuninger

M. Pannenberg

137 J.-St. Pischke

138 J. Zweimüller

R. Winter-Ebmer

139 R. A. Hart

Y. Ma

140 G. Brunello

S. Comi

141 R. Hujer

M. Wellner

142 J. J. Dolado

F. Felgueroso

J. F. Jimeno

143 P. J. Luke

M. E. Schaffer

144 G. Saint-Paul

145 M.-S. Yun

146 T. K. Bauer

J. P. Haisken-DeNew

147 M. Belot

J. C. van Ours

148 L. Goerke

149 R. Lalive

J. C. van Ours

J. Zweimüller

150 J. DiNardo

K. F. Hallock

J.-St. Pischke

151 M. Ward
Hiring and Firing Costs, Adverse Selection and

Long-term Unemployment

Is There a Wage Premium for Returning Irish

Migrants?

Unemployment and Productivity Growth: An

Empirical Analysis within the Augmented Solow Model

Continuous Training in Germany

$3 / 00$

Firm-specific Training: Consequences for Job Mobility

Wages, Hours and Human Capital over the

Life Cycle

Education and Earnings Growth: Evidence from 11

European Countries

The Effects of Public Sector Sponsored Training on Individual Employment Performance in East Germany

Explaining Youth Labor Market Problems in Spain: 3 Crowding-Out, Institutions, or Technology Shifts?

$4 / 00$

Wage Determination in Russia: An Econometric Investigation

Flexibility vs. Rigidity: Does Spain have the worst of 1 both Worlds?

Decomposition Analysis for a Binary Choice Model 7

$4 / 00$

Employer Learning and the Returns to Schooling

5

$4 / 00$

Does the Recent Success of Some OECD

Countries in Lowering their Unemployment Rates

Lie in the Clever Design of their Labour Market

Reforms?

Employment Effects of Labour Taxation in an Efficiency Wage Model with Alternative Budget Constraints and Time Horizons

The Impact of Active Labor Market Programs and Benefit Entitlement Rules on the Duration of Unemployment

Unions and the Labor Market for Managers 
J. F. Jimeno

153 A. S. Kalwij

M. Gregory

154 M. Gerfin

M. Lechner

155 J. Hansen

156 C. Dustmann

F. Fabbri

157 P. Apps

R. Rees

158 A. Björklund

T. Eriksson

M. Jäntti

O. Raaum

E. Österbacka

159 P.- J. Jost

M. Kräkel

160 M. Lofstrom

161 V. Gimpelson

D. Treisman

G. Monusova

162 C. Dustmann

M. E. Rochina-

Barrachina

163 R. A. Hart

Y. Ma

164 M. A. Shields

S. Wheatley Price

165

P. J. Pedersen

166 Z. MacDonald

M. A. Shields

167 A. Barrett

J. FitzGerald

B. Nolan

168 G. S. Epstein

A. L. Hillman
State: An Appraisal

Overtime Hours in Great Britain over the Period 3

1975-1999: A Panel Data Analysis

Microeconometric Evaluation of the Active Labour 6

$5 / 00$

Market Policy in Switzerland

The Duration of Immigrants' Unemployment Spells: $\quad 1 / 3$

Evidence from Sweden

Language Proficiency and Labour Market Per- 1

formance of Immigrants in the UK

Household Production, Full Consumption and $\quad 7$

the Costs of Children

Brother Correlations in Earnings in Denmark, 5

Finland, Norway and Sweden Compared to the

United States

Preemptive Behavior in Sequential Tournaments

5

$5 / 00$

A Comparison of the Human Capital and Signaling Models: The Case of the Self-Employed and the 5 Increase in the Schooling Premium in the 1980's

Public Employment and Redistributive Politics: 4 Evidence from Russia's Regions

Selection Correction in Panel Data Models: An 6 Application to Labour Supply and Wages

Why do Firms Pay an Overtime Premium?

5

$6 / 00$

Racial Harassment, Job Satisfaction and Intentions

5

$6 / 00$ to Quit:

Immigration in a High Unemployment Economy: 1 The Recent Danish Experience

The Impact of Alcohol Consumption on Occupa- 5 tional Attainment in England

Earnings Inequality, Returns to Education and 5 Immigration into Ireland

Social Harmony at the Boundaries of the Welfare 3 State: Immigrants and Social Transfers 
Immigration Policy in Integrated National

Wages and the Demand for Health - A Life Cycle Analysis

Reforming the Financial Incentives of the Welfare

Self-Employment and Earnings among High-

Industrial Relations and the Wage Differentials

between Skilled and Unskilled Blue-Collar

Workers within Establishments: An Empirical

Analysis with Data of Manufacturing Firms

Immigrant Adjustment in Israel: Literacy and

178 R. Euwals M. Ward

179 E. Wasmer

P. Weil

Fluency in Hebrew and Earnings

The Renumeration of British Academics

The Macroeconomics of Labor and Credit Market Imperfections

180 T. K. Bauer

I. N. Gang

Sibling Rivalry in Educational Attainment: 
A. S. Kalwij

The Myth of Worksharing

A. Zaidi

Is Unemployment Really Scarring? Effects of

193 A. Kunze

Absolute Risk Aversion and the Returns to Education

The Determination of Wages and the Gender Wage Gap: A Survey

194 A. Newell

Regional Unemployment and Industrial Restructuring in Poland 